\title{
Game Design as STS Research
}

\author{
JOSEPH DUMIT ${ }^{1}$ \\ UNIVERSITY OF CALIFORNIA, DAVIS
}

\begin{abstract}
Game design offers a powerful pedagogical paradigm for engaging students in thinking and researching sociotechnical systems. Using the example of designing a game around fracking, this paper describes how game design grapples with emergent dynamic processes, and how students are drawn into becoming STS researchers.
\end{abstract}

\section{Keywords}

STS; pedagogy; game studies; capitalism

In late industrialism, as I've conceptualized it, disasters like [Flint Michigan] are everywhere, eminent and normal - and normal not only in Charles Perrow's sense, emergent from tightly coupled industrial systems like nuclear power plants (Perrow 1984), but emergent from tight coupling between natural, technical, political-economic, social, and discursive systems, all of which are aging, often over-wrought, ossified, and politicized... I began to think in terms of late industrialism in recognition of the limits of available critical constructs for explaining issues of particular concern within environmental politics...

-Kim Fortun ${ }^{2}$

${ }^{1}$ Joseph Dumit, Email: dumit@ucdavis.edu

2 The sentence continues: "[within] the complexity and current state of ecological systems; the complex relationship between ecosystem and human health, and between the health of humans, rats, mice, and other sentinel species; the longue durée in which environmental problems become manifest, and consequent governance challenges; the largely unregulated, much less maintained, aging of our industrial infrastructure; the emergence of new modes of high-risk industrial activity (deep-water drilling for oil, shale gas extraction through hydrofracking); the continuing productivity of industrial culture and desire, with high throughput of consumers who love and depend on toxic products; increasingly intricate interlacing of commercial interests in what counts as scientific knowledge; the sobering and funny role of language and language ideology in the making of the world (Fortun 2014; see also Fortun 2012).

Copyright (C) 2017 (Joseph Dumit). Licensed under the Creative Commons Attribution Non-commercial No Derivatives (by-nc-nd). Available at estsjournal.org. 


\section{STS Pedagogy}

One of the biggest challenges in STS and social science pedagogy is providing students and citizens with a means of thinking analytically and critically about the interconnected world system within which science, facts, politics, and economics happen. Theories can seem to be too abstract, and yet, given an empirical problem, we all can be overwhelmed by how each aspect calls forth and relates to every other one. Even for experienced researchers, grappling with emergent dynamics at multiple scales seems to be an increasing challenge, as Kim Fortun explains in the epigraph above. One solution that Fortun has been pursuing in response to this is a collective database (AsthmaFiles), a strategy that was also used to organize against fracking's secrecy by Theo Colburn and described by Sara Wylie (TEDX). These bottom-up and crowdsourced approaches to knowledge creation are necessary because one key corporate strategy is the control, obfuscation, and deletion of information. Wylie's work on fracking raised the additional challenge of understanding how and why corporations act in a way that seems to be in no one's long term interest (2018). In this short paper, I want to offer an extra conceptual tool, one that works well at all levels, including undergraduate, graduate and community teaching: reimagining research challenges as a game.

By talking about games, I do not mean "gamifying" research or teaching_attempting to increase motivation through an additional layer of rewards (Bogost 2011; Walz and Deterding 2015). Rather, I want to engage in the process of imagining a new boardgame or digital game about some aspect of the research or the social problem students are studying. Games are interesting tools because they involve the game player creatively within a dynamic system, requiring them to make decisions under constraints.

Through playing the game, the player obtains a feel for the emergent dynamics that result from the various parts interacting. This includes emergent effects that may not be explicitly represented in the rules at all. Game designer and theorist Jonathan Blow explains that we use systems to answer questions about the world (he might have said models but that means something different in game design), and games are one means of using systems that we can listen to in order to learn about the world (2011). Fellow designer/theorist, Richard Terrell, builds on this:

Of course it helps when the output is such that we can perceive and appreciate what's happening in the system. A spreadsheet and a graph can contain the same data points, yet a graph may be far more appreciable to more people. This is what Blow means when he talked about making emergence "appreciable to the senses." Feedback and form are clearly important parts of the way we learn and use systems (Terrell 2011). 
In many games, the player gains this dynamic understanding precisely because their point of view is now situated within the game: as an avatar in a first-person video game, as a general in Risk, or as a type of real-estate investor in Monopoly. It is from this situated position that decisions are evaluated through anticipating possible futures that could play out within the dynamics of the game states and responses of the other players. We all understand this; the analogy is the basis of Bourdieu's (1990) theory of habitus as a "feel for the game" and the fact that one gains through the situated experience of negotiating a complex social system from a firstperson perspective in which one's decisions matter.

Thinking about designing a game affords a fascinating possibility: the chance to try and represent the emergent dynamics of a situation we are interested in with as much depth as desired. Radical game designer Paulo Pedercini writes: "Games and simulations can simplify and mirror certain aspects of real world systems while maintaining their dynamic properties. By playing games and, even more so, by making games, we can promote this kind of literacy" (2013). Pedercini has done this through a series of classes, workshops, and fascinating games. One of them, Oiligarchy, puts the player in the position of a multinational oil company. He explained his approach as one of anti-reductionism:

The expressive and rhetorical potential of games lies in their ability to depict complex systems in an approachable way (rather than using narrative strategies)...The creation of this dynamic model, more than the user interaction, would discourage reductionist approaches to the problem... and hypothetically foster a new kind of holistic critical thinking (Pedercini 2008).

Creating a game about a topic can reveal for the designer and then the player how dynamic forms like structural inequality and ignorance are produced through interactions. Nicky Case points out that critical games are about "changing knowledge first; this is not gamification which is about changing behavior" (Case 2014). Though we must not think that knowing how inequality is produced is the same as thinking that it is bad. The designer of the original Monopoly game, Elizabeth Magie, wanted her Landlord's Game to teach about the evils of systems that reward monopolies (Pilon 2015).

Nonetheless, designing games with complex systems requires research that attends to dynamic properties. What happens when we frame research on an industry (or topic, issue, discipline, lab) as designing a game? Does the attempt to model the dynamic feedback among actors inform a more critical analysis of the factors that shape emergent phenomena? The 
freedom to add almost anything to a game during the design phase can suggest connections and relationships that might otherwise be overlooked or taken for granted. Designers become curious, asking, What effects are emerging here, and what are the various constraints on them? The world comes to be seen imploded in every object (Haraway 1997; Dumit 2014) in an interesting and not overwhelming way. In this manner, designing a game invites STS for its expertise in studying and addressing these questions.

\section{Frack: The Game}

Embracing the abstraction is a willingness to take that critical first step of opening your mind to, at the very least, consider points of view other than your own. -Richard Terrell

by Pedercini and others, I created an undergraduate class around designing a game about fracking and co-taught it with Whitney Larrat-Smith who was studying the Tar Sands. The premise provided to the students was simple: In the game you play a fracking company and the goal is to grow your company as big as possible, before the world ends. The subtitle is: "Taking it With You." The other subtitle is "The Game We Are Already Playing."

I began the class by asking the students: What do fracking companies do? The answers were predictably lackluster and focused on money, production, and advertising. I then went around the room and asked them: What superpowers would you want to have if you are a fracking company and want to grow as much as possible? Here they collectively generated a much more expansive list of actual concerns: reducing regulations, keeping newspapers in line, producing friendly science, sabotaging other companies, absorbing competitors. Surprisingly, when I complimented them on their insights, they responded by asking: But can you really do these things?

Research involved figuring out the actors involved and how they interacted. Histories, popular accounts, documentaries, and news articles were first used to start to diagram the dynamics. What affected what and how? What counted as an event? What sort of feedback and contingency created each event? At the same time, what made it newsworthy? Who were the actors in the event? Who decides what is an actor? What forms of direct action came into play by all actors? In their analysis of news they noted how public relations worked to frame controversies in some ways rather than others. Through thinking about how news could affect various actors, especially companies, they began to see how the media was part of constructing worlds. Without introducing the terms, they began to formulate different theories of ideology, 
public relations, and visibility (in a Foucauldian sense). At this point they were asking for "theory" (of media, public relations, capitalism, etc.) to help them make sense of the concepts they were grasping toward, and when they read it, they read it critically, checking it against what they were observing in the world and asking whether it helped them design better analytics (game mechanics) or not.

In asking them to design a game in which the players would be fracking companies, I was asking them to step into the point of view (POV) of a company, to map the world that they live in, to figure out what corporations care about. Precisely by taking on the POV of a company and asking, "How could I influence this to make it friendlier to my goals," they began to see the news as intervening in the world rather than reporting on it. They could then read and understand Wylie's STS query, "Why are former MITEI head Moniz's supportive statements framed as 'policy recommendations' and not 'advocacy,' while Volz's dissenting statements are counted against him as advocacy?" (Wylie 2011, 321).

By assigning students to discover and read the grey literature that companies write to each other-e.g., Oil and Gas News, "Executive Oil Conference," OilPrice.com-they could see the topics as a map of matters of concern. This quickly brought up the issue of speculation over estimates. Controlling the PR on how much gas was in a shale and how expensive it would be to extract: this could have a far bigger impact on a company than anything else. Even before it was verified, these geologic estimates are the "future" contracted into the present share price, which becomes a fluctuating measure of the company's ability to maneuver. Accusations of under- and over-estimation were common. By contrast, activism and even regulation were relatively less important to companies than corporate buyouts and the relative state of other markets.

As they brought these insights to discussion, they could then debate how they could be abstracted into actions that a game player/company could take, and consequences for the state of the game. One week they read economic literature on shale exploration, speculative financing, fracking costs, pipeline costs, and market movements. They then had a discussion about the algorithms that could best reflect the complexities of these interactions.

As the students read critical analyses of fracking that traced corporate tactics they became increasingly intrigued with the power and reach of what Wylie calls "informatic techniques of corporate disembodiment" (Wylie, forthcoming 2018). These include the ways in which companies can literally erase their tracks in the world through exemptions to being surveyed or monitored by the EPA, non-disclosure agreements in lawsuits that prevent those who are harmed from telling their stories, and holding corporations that disaggregate actions. 
They also regularly hire former regulators, creating cozy relationships with the government agencies that are supposed to keep them in check.

\section{Game Design Becomes Analysis}

To embody the role is to reinvent it. -Francesca Coppa

To sum up, by framing the class around how to design a game about fracking, students were freed up psychologically as well as ideologically. The idea that they were designing a game enabled them to feel empowered to read across technical fields with real purpose: what insights does this give me into what a company cares about and is capable of? What mattered for how a company made this decision? Rather than trying to get the "right" answer to these questions, they used mapping strategies to account for all of the potential actors or stakeholders in a scenario (reminiscent of Adele Clark's (2005) grounded theory approach). In so doing, they became quite hungry for STS theories, for cultural anthropological approaches, and for media studies critiques. Each of these gave them unique insights into the world they were designing, and helped them make their game better, in the sense of giving them better strategies for researching the game, better embodying the dynamics of the world in it, and better positioning the player as a corporation in this case.

Trying to see all events from a corporate POV often produced a type of epistemological whiplash: students came to understand how it could be that the ways in which something they found awful, also "made sense"; that disasters were normal, in Kim Fortun's terms; that the destruction of the environment was an emergent outcome of the current relations of production. Their analysis of the grey literature made clear that companies and citizens often do not share worlds-in the sense that they do not care about or even notice the same things. ${ }^{3}$ The actor networks that each makes up are not the same. This led to a deep discussion about multiple worlds and ontologies--concepts that the students were able to wrestle with because they helped them think through the game that they were making.

One week, I asked the students to research the ways in which people were protesting fracking. They were to analyze these and come to class prepared to share and defend what they thought was the most effective strategy. These included everything from lawsuits to newsletters

\footnotetext{
3 They were chagrined to find that even energy executives such as Rex Tillerson could be trying to stop fracking locally at the same time that they were promoting it globally (Leber 2014).
} 
to marches to celebrity sponsorship to films. Then we went around again and this time I asked everyone to imagine the best way, as a company, to counter or pre-empt these strategies. This activity was a bit disheartening, but it also brought to light the vast difference in economic power, the resources that the corporate side could bring to bear on a situation, the people it could mobilize, and the access it had to power structures like the state, media, regulatory agencies, lawmakers, and police. It could put the burden of proof on the protesters and cause them to take time, energy, and money and spend them defending their activities. These were all resources that were not spent on investigating or mitigating the damage that the industry was doing. This became another action that companies could use in the game. ${ }^{4}$

In workshops where I explain this approach to game design as research with faculty, graduates, and community members, I challenged each of them to make a map of all the actors in their field of concern, at multiple scales. Then, drawing on game design principles, I ask them to generate a list of verbs for each actor: what do they do? From this they can select points of view that they took for granted or avoided identifying with, and then they can start to draw the dynamic interactions taking place from that point of view. This then became a starting point for designing a game. Taking up, e.g., the petrochemical industry from the point of a corporation (or some part of a corporation) and its doings, provides a preliminary map of lines of force and interest, one that emphasizes the fragility of the corporation-how challenging its decisions are, how difficult the system is to maintain. This can be seen as an intellectual contribution to activism as described by Foucault:

What's effectively needed is a ramified, penetrative perception of the present, one that makes it possible to locate lines of weakness, strong points, positions where the instances of power have secured and implanted themselves...(Foucault 1980, 62).

Psychologically, the "serious play" of designing of a game, seems to free our imagination to attempt to embody a complex dynamic sociotechnical system. Importantly, the game does not have to be finished to be useful. Collectively workshopping a game idea provides a format in which suggestions can be discussed for how they interact, and even incorporated without

\footnotetext{
${ }^{4}$ In the class, we prototyped the game using other board games, and we created a website to share the process (http: / / frackthegame.com). The long-term intention was to then create a digital game. That game is now in production at ModLab (http://modlab.ucdavis.edu) being created and built with a team of researchers and designers including: Josef Nguyen, Patrick LeMieux, Stephanie Boluk, Owen Marshall, Ranjodh Singh Dhaliwal, Evan Lauteria, and Colin Milburn.
} 
immediately having to ask if they are relevant. Game design is thus a method, a paper tool (Klein 2003) for thinking together about science, facts, politics, and economics.

By ignoring the serious play of games, the social sciences have left this rich terrain for teaching and analysis in the hands of economics and consumer culture. Game design is an underexamined and often ignored aspect of systems thinking and engagement with which the social sciences would do well to experiment. Whereas social and STS theory emphasize how emergent systems give rise to structures and events, designing a game scales the process down to the step-by-step speed of individual decisions, offering insights into how different systems interact. STS scholars can build on the work of critical game designers and theorists to understand the challenges of late industrialism.

\section{Author Biography}

Joseph Dumit is an anthropologist of sciences, passions, brains, games, bodies, drugs and facts who functions as chair of Performance Studies, director of the Institute for Social Sciences, and professor of Science \& Technology Studies and Anthropology at the University of California, Davis. http:// dumit.net

\section{Acknowledgements}

Thanks to ModLab, Colin Milburn, Sara Wylie, Michelle Murphy, Sylvia Sensiper, and numerous workshop participants for their critical engagement. Funding for this research was provided by Social Science Research Council of Canada (IMMERSe), Research Council of Norway (SAMKUL), and UC Davis IFHA grant.

\section{References}

Blow, J. 2011. "Truth in Game Design." presented at the Game Developers Conference Europe. http:/ / gdcvault.com/ play/1014982/Truth-in-Game.

Bogost, I. 1990. "Gamification Is Bullshit.” http://bogost.com/writing/blog/ gamification_is_bullshit/.

Bourdieu, P. 1990. The Logic of Ppractice. Stanford University Press.

Case, N. 2014. “Explorable Explanations.” https:/ / web.archive.org/web/20160324090415/ http://blog.ncase.me/explorable-explanations/. 
Clarke, A. 2005. SituationalAnalysis: Grounded Theory After thePpostmodern Turn. Thousand Oaks, CA: Sage Publishing.

Coppa, F. 2-14. "Writing Bodies in Space: Media Fanfiction as Theatrical Performance." In Fan Fiction Studies Reader, edited by Karen Hellekson and Kristina Busse, 218-37. Iowa City: University of Iowa Press.

Dumit, J. 2014. "Writing the Implosion: Teaching the World One Thing at a Time." Cultural Anthropology 29(2): 344-62. doi:10.14506/ ca29.2.09.

Fortun, K. 2012. "Ethnography in Late Industrialism." Cultural Anthropology 27(3):446-64.

—. 2014. "From Latour to Late Industrialism." HAU: Journal of Ethnographic Theory 4(1) 30929. doi:10.14318/hau4.1.017.

Foucault, M. 1980. Power/knowledge: Selected interviews and other writings, 1972-1977. Pantheon Press.

Haraway, D. J.1997. Modest_Witness@Second_Millennium.FemaleMan_Meets_OncoMouse: Feminism and Technoscience. New York: Routledge.

Klein, U. 2003. Experiments, Models, Paper Tools: Cultures of Organic Chemistry in the Nineteenth Century. Stanford University Press.

Kremer, M. and R. 2016. Glennerster. Strong Medicine: Creating Incentives for Pharmaceutical Research on Neglected Diseases. Princeton University Press.

Leber, R 2014. "Exxon CEO Comes Out Against Fracking Project Because It Will Affect His Property Values." ThinkProgress. <https://thinkprogress.org/exxon-ceo-comes-outagainst-fracking-project-because-it-will-affect-his-property-values-99afafd154f8>.

Pedercini, P. 2013. "Designing Games to Understand Complexity." Molleindustria. http:// www.molleindustria.org/blog/designing-games-to-understand-complexity/.

—. 2008. “Oiligarchy Postmortem. Molleindustria. http://www.molleindustria.org/ oiligarchy-postmortem/.

Pilon, M. 2015. “Monopoly's Inventor: The Progressive Who Didn't Pass 'Go.'” The New York Times. http:/ / www.nytimes.com/2015/02/15/business/behind-monopoly-an-inventorwho-didnt-pass-go.html.

Terrell, R. 2011. “Critical-Gaming Network—Blog—Digital Truth: Emergent Origins pt.1.” http: / / critical-gaming.com/blog/2011/10/4/digital-truth-emergent-origins-pt1.html.

—. 2012. "Critical-Gaming Network-Blog_Embrace The Abstraction." http://criticalgaming.com/blog/2012/1/27/embrace-the-abstraction.html.

Walz, S. P. and S. Deterding, eds. 2015. The Gameful World: Approaches, Issues, Applications. Cambridge, Massachusetts: The MIT Press. 
Wylie, S. 2011. Corporate bodies and chemical bonds: an STS analysis of natural gas development in the United States. PhD Dissertation. MIT Program in Science, Technology and Society. http: / hdl.handle.net/1721.1/69453

Wylie, S. (forthcoming, 2018) Fracking: Corporate Bodies and Chemical Bonds. Durham: Duke University Press. 